\title{
FAKTOR UTAMA PEMILIHAN LOKASI KAFE DI KOTA SURAKARTA
}

\author{
Muhammad Khoirul' ${ }^{1}$, Galing Yudana' ${ }^{1}$ Paramita Rahayu ${ }^{1}$ \\ ${ }_{1}^{1}$ Program Studi Perencanaan Wilayah dan Kota Fakultas Teknik Universitas Sebelas Maret Surakarta
}

\begin{abstract}
Abstrak
Salah satu kota di Indonesia yang mengalami perkembangan yang sangat pesat berkaitan dengan bisnis kafe adalah Kota Surakarta. Jumlah restoran atau tempat makan di Kota Surakarta yang di dalamnya termasuk kafe mengalami peningkatan lebih dari dua kali lipat dalam kurun waktu dari tahun 2014 hingga 2015. Lokasi kafe di Kota Surakarta tersebar di sekitar kawasan perdagangan dan kawasan permukiman. Keberadaan beberapa kafe di kawasan permukiman terkadang memberikan beberapa permasalahan, seperti kemacetan dan kebisingan dari aktivitas kafe. Oleh karena itu, penelitian ini bertujuan untuk menentukan faktor utama yang berpengaruh dalam pemilihan lokasi kafe di Kota Surakarta sehingga bisa menjadi salah satu masukan dalam pengaturan aktivitas di Kota Surakarta terutama yang berkaitan dengan aktivitas perdagangan dan jasa. Penelitian ini menggunakan pendekatan deduktif dan termasuk dalam penelitian denganmetode kuantitatif. Teknik analisis yang digunakan untuk mengungkapkan faktor pemilihan lokasi kafe di Kota Surakarta adalah analisis faktor. Data yang digunakan sebagai input untuk analisis faktor adalah data yang diperoleh dari kuesioner penilaian dengan skala likert yang diisi oleh para pemilik kafe di Kota Surakarta terkait dengan faktor-faktor pemilihan lokasi saat akan mendirikan usaha kafe. Berdasarkan hasil analisis faktor diperolehempat kelompok faktor yang menggambarkan karakter pemilihan lokasi kafe di Kota Surakarta. Kelompok faktor yang mempengaruhi pemilihan lokasi kafe di Kota Surakarta yaitu fleksibilitas lokasi, kesesuaian lokasi, dukungan sekitar lokasi, dan faktor tambahan. Fleksibilitas lokasi yaitu kemudahan lokasi untuk ditemukan dan masyarakat bisa dengan nyaman mencapainya. Kesesuaian lokasi yaitu kemampuan dari lokasi terpilih untuk dapat mengakomodasi kebutuhan dari kegiatan kafe yang akan dijalankan. Dukungan sekitar lokasi yaitu elemenelemen yang ada di sekitar lokasi yang bisa menunjang dan mempermudah dalam kegiatan operasional kafe. Faktor tambahan adalah faktor yang tidak signifikan memberikan pengaruh dalam pemilihan lokasi kafe di Kota Surakarta.
\end{abstract}

Kata kunci: analisis faktor; lokasi; kafe; Surakarta

\begin{abstract}
One of the cities in Indonesia that experienced a very rapid development related to the cafe business is Surakarta. The number of restaurants or eating places in Surakarta which includes cafés has more than doubled in the period from 2014 to 2015. The location of cafes in Surakarta is spread around commercial areas and residential areas. The existence of several cafes in residential areas sometimes gives some problems, such as congestion and noise from the activity of the cafe. Therefore, this study aims to determine the main factor in the selection of cafe location in Surakarta so that it can be one of the inputs in the regulation of activities in Surakarta, especially related to trading and services activities. This research uses deductive approach and included in research with quantitative method. The analytical technique used to reveal the café location selection factor in Surakarta is factor analysis. The data used as input for factor analysis is data obtained from the questionnaire questionnaire with Likert scale filled by the cafe owners in Surakarta related to the factors of location selection when will establish cafe business. Based on the result of factor analysis, there are four groups of factors that describe the character of choosing cafe location in Surakarta. Factor groups that influence the selection of cafe location in Surakarta are location flexibility, location compatibility, support around location, and additional factors. The flexibility of the location is the ease of location to be found and the public can comfortably reach it. The suitability of the location is the ability of the selected location to be able to accommodate the needs of the cafe activities to be operate. Support around the location of the elements that exist around the location that can support and simplify the operational activities cafe. Additional factor is a factor that does not give significant influence in the selection of cafe location in Surakarta.
\end{abstract}

Keywords: café; factor analysis; location; Surakarta

\section{PENDAHULUAN}

Lokasi merupakan dasar untukmenentukan posisi dari aktivitas yang dilakukan oleh manusia (Tarigan, 2005:77). Sosiolog Ray Oldenburg menjelaskan bahwa lokasi secara umum dibagi menjadi dua, yaitu "The First Place (lokasi pertama)" dan "Second Place (lokasi kedua)" (Oldenburg, 1997:6). The First Place merupakan gambaran mengenai lokasi 
yang dimanfaatkan sebagai tempat tinggal, sedangkan second place merupakan lokasi yang dimanfaatkan untuk bekerja atau melakukan aktivitas harian.

Dalam perkembangannya manusia membutuhkan tempat-tempat alternatif selain ruang untuk tempat tinggal dan tempat untuk menghabiskan sebagian besar waktunya. Manusia yang hakikatnya merupakan makhluk sosial senantiasa membutuhkan wadah untuk melakukan interaksi dengan manusia yang lain. Ruang alternatif yang merupakan wujud dari sarana untuk melakukan interaksi bersama anggota keluarga, teman, atau orang lain, selanjutnya disebut sebagai "third place" (Oldenburg, 1997:6). Third place sendiri dapat berbentuk berbagai macam, antara lain: tempat potong rambut, perpustakaan, taman-taman, alun-alun kota atau kafe (Bernhardt dan Stoll, 2010:1).

Kafe yang menjadi salah satu representasi dari third place saat ini tidak hanya dipandang sebagai tempat untuk meminum kopi, akan tetapi juga sebagai ruang sosial yang telah dikonsep ulang menjadi ruang-ruang berkumpul alternatif yang memungkinkan memiliki keterikatan dengan kondisi ruang pribadi sehari-hari (Maharani, 2016:11). Hal ini terlihat dari jumlah kafe di Indonesia yang mengalami perkembangan pesat, terutama di kota-kota besar di Indonesia, seperti: Jakarta, Bandung, Yogyakarta, dan Surabaya. Jumlah kafe di Indonesia saat ini diperkirakan telah lebih dari 10.000 kafe dan diprediksi akan memberikan nilai ekonomi sebesar USD 4,16 miliar pada akhir tahun 2018 (Septiyaning, 2016).

Kota Surakarta pada periode 2015,memiliki jumlah restoran yang di dalamnya termasuk kafe lebih dari 800 restoran.Jumlah tersebut berkembang cukup signifikan dari tahun 2014 yang hanya berjumlah sekitar 300 restoran (Bisnis Kuliner di Kota Solo Melonjak, www.solopos.com, 21 Maret 2016). Salah satu faktor yang menyebabkan jumlah kafe mengalami peningkatan adalah perubahan nilai-nilai masyarakat yang saat ini lebih memilih tempat-tempat alternatif lain seperti kafe untuk berinteraksi atau bersosialisasi dari pada ruang terbuka umum karena kondisi kuantitas dan kualitas ruang terbuka umum yang masih rendah (Pamungkas, 2017).

Pertumbuhan kafe yang terjadi memiliki kontribusi yang positif terhadap perkembangan kota, salah satunya menyangkut penyerapan tenaga kerja dan juga peningkatan Pendapatan Asli Daerah (PAD) dari sektor usaha. Akan tetapi, perkembangan kafe di Kota Surakarta juga memberikan beberapa permasalahan. Kedekatan beberapa kafe dengan aktivitas lain yang memiliki karakter berbeda, seperti permukiman sering kali menimbulkan konflik. Mulai dari arus lalu lintas yang terganggu karena penggunaan bahu jalan sebagai ruang parkir hingga polusi suara dari musik yang dimainkan dari dalam kafe merupakan beberapa permasalahan yang sering terjadi berkaitan dengan lokasi kafe. Keadaan tersebut bila tidak segera diselesaikan akan membuat kehadiran dari kafe justru menjadi kontra produktif dengan perkembangan kota.

Oleh karena itu, kehadiran kafe saat ini perlu dikelola dan ditata dengan baik agar bisa memberikan manfaat yang lebih besar bagi perkembangan Kota Surakarta. Perkembangan kafe mungkin bisa diarahkan ke ruang-ruang kota yang sesuai dengan karakter dan kebutuhan kafe sehingga dampak negatif yang dihasilkan bisa dikurangi karena telah disiapkan langkah-langkah antisipasi sebelumnya. Dari permasalahan yang terjadi kemudian muncul pertanyaan penelitian mengenai "faktor apakah yang menjadi pertimbangan utama dalam pemilihan lokasi kafe di Kota Surakarta". Penelitian ini memiliki tujuan untuk menemukan faktor utama dalam pemilihan lokasi kafe di Kota Surakarta sehingga selanjutnya bisa dimanfaatkan oleh berbagai pihak terutama bagi pemerintah dalam mengambil kebijakan selanjutnya terkait dengan pengetahuan lokasi kafe.

\section{KAJIAN TEORI}

Restoran adalah suatu kegiatan atau usaha yang memberikan pelayanan jasa berupa makanan dan minuman. Restoran informal merupakan restoran yang mengutamakan suasana santai dan tidak terlalu mengikat. Salah satu contoh dari restoran informal adalah kafe.

Kafe adalah penyedia makanan dan minuman ringan yang dilengkapi dengan peralatan dan perlengkapan untuk proses pembuatan, penyimpanan dan/atau penyajiannya, di dalam satu tempat tetap yang tidak berpindah-pindah (Permen Parekraf 10 Tahun 2014). Damajani (2008: 141) menyatakan bahwa kafe adalah tempat yang dimanfaatkan untuk meminum kopi disertai dengan panganan kecil atau panganan ringan. Kafe bisa digambarkan sebagai lokasi yang memiliki ciri menyediakan minuman ringan biasanya berupa kopi dan makanan ringan dalam suatu bangunan permanen yang tetap dan tidak berpindah-pindah.

Dahulu kafe yang umumnya disebut sebagai kedai kopi merupakan suatu tempat yang kurang nyaman, kurang menarik, dengan suasana yang relatif monoton (Hariwan dan Silviatni, 2014:54). Namun, seiring perkembangan jaman 
kafe telah banyak mengalami perubahan atau pergeseran terutama berkaitan dengan fungsi kafe itu sendiri (Damajani, 2008:144). Kafe yang ada saat ini telah memberikan konsep suasana yang berbeda sehingga pengunjungnya tidak hanya didominasi oleh orang-orang dewasa, akan tetapi anak-anak muda baik itu pria atau wanita juga sudah mulai meramaikan tempat ini. Beragam kegiatan mulai dari membaca buku hingga melakukan berbagai pertemuan juga sudah mulai sering dilakukan di kafe karena suasana nyaman yang dapat dihadirkan. Kafe yang semula merupakan tempat untuk meminum kopi saat ini telah berubah menjadi ruang publik alternatif (Damajani, 2008:144).

Kafe yang mulai tumbuh di kemudian haritelah mengalami banyak penyesuaian mulai dari konsep, aktivitas yang terwadahi, hingga pada penempatan lokasi kafe. Kafe yang ada saat ini telah menempati ruang yang cukup luas di sudutsudut kota dan beberapa deretan toko modern (Maharani, 2016:2). Letak dari setiap kafe juga sangat beragam dan tidak tersebar secara merata. Ada lokasi yang disitu tumbuh banyak kafe akan tetapi ada lokasi lain yang jumlah kafenya terhitung sedikit. Hal tersebut tidak terlepas karena antara satu lokasi dengan lokasi yang lain kerap kali mempunyai perbedaan kondisi sehingga memunculkan suatu keunggulan komparatif yang merupakan kelebihan yang dimiliki oleh suatu lokasi.

Oleh karena itu, seperti kegiatan yang lain pemilihan lokasi untuk kafe merupakan salah satu hal yang paling penting karena lokasi akan sangat menentukan kebutuhan faktor input serta skala operasi dari bisnis yang dapat mempengaruhi keseimbangan antara biaya operasi dan pemasukan yang didapatkan (Goodall, 1972:115). Pemilihan lokasi juga perlu dilakukan secara matang dan dilakukan dengan penuh kehati-hatian karena kesalahan dalam penempatan akan menjadi kelemahan dari aktivitas. Dalam prosesnya diperlukan berbagai pertimbangan mengenai faktor-faktor terkait yang ke depan akan memberikan peluang ataupun tantangan terhadap keberlanjutan dari bisnis kafe.

Berikut ini merupakan elaborasi dari penelitian-penelitian terdahulu mengenai pemilihan lokasi usaha atau bisnis dan pemilihan lokasi restoran. Faktor-faktor tersebut kemudian disintesis untuk mendapatkan variabel terpilih yang akan digunakan dalam tahap selanjutnya.

Tabel 1. Sintesis Literatur

\begin{tabular}{|c|c|c|}
\hline Variabel & Penjelasan & Sumber \\
\hline Aksesibilitas & $\begin{array}{l}\text { Lokasi terpilih yang akan digunakan sebagai tempat bisnis ke depan } \\
\text { merupakan lokasi yang mudah dijangkau atau dilalui. Kemudahan untuk } \\
\text { mencapai lokasi haruslah terpenuhi agar konsumen tidak banyak } \\
\text { mengeluarkan waktu dan biaya yang berlebihan untuk menuju lokasi } \\
\text { sehingga meningkatkan kenyamanan dari konsumen. }\end{array}$ & $\begin{array}{l}\text { Tjiptono dan Chandra (2011); } \\
\text { Wahyudi (2014); Ariani (2009); } \\
\text { Zuliarni dan Hidayat (2013); Indarti } \\
\text { (2004); Park dan Khan (2005); } \\
\text { Smith (1985); Chen dan Tsai } \\
\text { (2015); Tzeng, dkk (2002) }\end{array}$ \\
\hline Lingkungan & $\begin{array}{l}\text { Kondisi lingkungan yang kondusif baiknya diperhatikan dalam pemilihan } \\
\text { lokasi usaha. Dukungan yang didapatkan dari lingkungan sekitar akan } \\
\text { memudahkan dalam pengembangan kegiatan-kegiatan di masa yang akan } \\
\text { datang. }\end{array}$ & $\begin{array}{l}\text { Tjiptono dan Chandra (2011); } \\
\text { Wahyudi (2014); Ariani (2009); } \\
\text { Zuliarni dan Hidayat (2013); Indarti } \\
\text { (2004); Park dan Khan } \\
\text { (2005);Smith (1985); Chen dan } \\
\text { Tsai (2015); Tzeng, dkk (2002) }\end{array}$ \\
\hline $\begin{array}{l}\text { Peraturan } \\
\text { Pemerintah }\end{array}$ & $\begin{array}{l}\text { Aturan-aturan mengenai larangan terhadap beberapa aktivitas di suatu lokasi } \\
\text { seharusnya diperhatikan dengan baik dalam pemilihan lokasi. Dalam } \\
\text { melakukan pemilihan lokasi sebisa mungkin dapat membaca arah } \\
\text { perkembangan wilayah ke depan melalui aturan yang ditetapkan sehingga } \\
\text { bisa dikembangkan menjadi peluang untuk mendukung keberlangsungan } \\
\text { usaha. }\end{array}$ & $\begin{array}{l}\text { Tjiptono dan Chandra (2011); } \\
\text { Ariani (2009); Park dan Khan } \\
\text { (2005); }\end{array}$ \\
\hline Kompetitor & $\begin{array}{l}\text { Salah satu yang perlu dievaluasi dalam pemilihan lokasi adalah jumlah } \\
\text { restoran lain yang memiliki kesamaan produk dan layanan di sekitar lokasi. } \\
\text { Dengan mengetahui kekuatan kompetitor akan lebih memudahkan dalam } \\
\text { menempatkan lokasi usaha agar dapat bersaing dan mendatangkan } \\
\text { keuntungan. }\end{array}$ & $\begin{array}{l}\text { Tjiptono dan Chandra } \\
\text { (2011);Ariani (2009); Zuliarni dan } \\
\text { Hidayat (2013); Indarti (2004); } \\
\text { Park dan Khan (2005);Smith } \\
\text { (1985); Chen dan Tsai (2015); } \\
\text { Tzeng, dkk (2002) }\end{array}$ \\
\hline Parkir & $\begin{array}{l}\text { Keberadaan tempat parkir yang luas dan aman sebisa mungkin disediakan } \\
\text { oleh suatu lokasi usaha. Keberadaan tempat parkir akan meningkatkan } \\
\text { kenyamanan dari konsumen yang datang karena sering kali konsumen } \\
\text { datang menggunakan transportasi pribadi. }\end{array}$ & $\begin{array}{l}\text { Tjiptono dan Chandra (2011); } \\
\text { Ariani (2009); Zuliarni dan Hidayat } \\
\text { (2013); Indarti (2004); Park dan } \\
\text { Khan (2005);Chen dan Tsai } \\
\text { (2015); Tzeng, dkk (2002) }\end{array}$ \\
\hline
\end{tabular}




\begin{tabular}{|c|c|c|}
\hline Variabel & Penjelasan & Sumber \\
\hline Visibilitas & $\begin{array}{l}\text { Visibilitas merupakan kemudahan dari lokasi usaha untuk dilihat atau diamati } \\
\text { oleh konsumen dengan jelas pada jarak tertentu. Semakin mudah suatu } \\
\text { lokasi diamati oleh orang yang melintas akan meningkatkan kemungkinan } \\
\text { konsumen yang mengunjungi lokasi. }\end{array}$ & $\begin{array}{l}\text { Tjiptono dan Chandra (2011); } \\
\text { Ariani (2009); Zuliarni dan Hidayat } \\
\text { (2013); Park dan Khan } \\
\text { (2005);Chen dan Tsai (2015); }\end{array}$ \\
\hline $\begin{array}{l}\text { Ukuran } \\
\text { Lokasi }\end{array}$ & $\begin{array}{l}\text { Ukuran lokasi menyesuaikan dengan skala aktivitas yang akan dijalankan. } \\
\text { Permasalahan tentang ukuran lokasi sering kali terkait dengan ketersediaan } \\
\text { lahan yang bisa dimanfaatkan serta kemungkinan perluasan lokasi aktivitas } \\
\text { ketika ruang yang sudah digunakan tidak mampu menampung konsumen di } \\
\text { kemudian hari. }\end{array}$ & $\begin{array}{l}\text { Ariani (2009); Indarti (2004); Park } \\
\text { dan Khan (2005);Chen dan Tsai } \\
\text { (2015); }\end{array}$ \\
\hline $\begin{array}{l}\text { Tenaga } \\
\text { Kerja }\end{array}$ & $\begin{array}{l}\text { Dalam pemilihan lokasi usaha terkadang mempertimbangkan mengenai } \\
\text { ketersediaan tenaga kerja yang mempunyai keahlian sesuai dengan yang } \\
\text { dibutuhkan. Sumber daya manusia yang sesuai dengan kuantitas dan } \\
\text { kualitas dari bisnis yang akan dijalankan akan membuat operasional usaha } \\
\text { tersebut berjalan lancar. }\end{array}$ & Ariani (2009); Indarti (2004); \\
\hline Biaya & $\begin{array}{l}\text { Biaya yang dimaksud dalam pemilihan lokasi adalah biaya yang digunakan } \\
\text { ketika awal memulai usaha. Pertimbangan mengenai biaya yang dikeluarkan } \\
\text { serta kemungkinan pemasukan yang akan didapatkan akan mempengaruhi } \\
\text { pemilihan lokasi usaha, hal tersebut untuk menjaga keseimbangan keuangan } \\
\text { dari usaha agar dapat tetap bertahan. }\end{array}$ & $\begin{array}{l}\text { Wahyudi (2014); Indarti (2004); } \\
\text { Park dan Khan (2005); Tzeng, dkk } \\
\text { (2002) }\end{array}$ \\
\hline
\end{tabular}

\section{METODE PENELITIAN}

\subsection{Pendekatan dan Jenis Penelitian}

Penelitian untuk mengkaji faktor-faktor utama yang dipertimbangkan dalam pemilihan lokasi kafe di Kota Surakarta adalah penelitian dengan pendekatan secara deduktif. Penelitian ini menggunakan pendekatan secara deduktif karena untuk melihat faktor-faktor yang dipertimbangkan dalam pemilihan lokasi kafe di Kota Surakarta didasarkan pada teoriteori yang sudah ada yang kemudian diterapkan pada kasus terpilih.

Metode penelitian yang digunakan adalah metode penelitian kuantitatif. Penelitian kuantitatif adalah penelitian yang memandang fenomena-fenomena yang terjadi relatif tetap, konkret dan terukur (Sugiyono, 2009:8). Karakteristik dari penelitian ini adalah desain penelitiannya sudah spesifik, jelas, rinci, dan telah ditentukan sejak awal.Penelitian kuantitatif memiliki kecenderungan menggunakan metode analisis numerik atau angka sehingga pengolahan datanya melalui proses komputasi.

\subsection{Variabel Penelitian}

Variabel penelitian menurut Sugiyono (2009:38) adalah segala sesuatu yang ditetapkan oleh peneliti untuk selanjutnya dipelajari melalui data-data yang dihasilkan untuk memperoleh informasi yang akan menjadi suatu kesimpulan. Variabel yang sebelumnya didapatkan dalam proses elaborasi (Tabel 1) kemudian dijabarkan ke dalam bentuk operasional sehingga memudahkan dalam proses pencarian data dan analisis. Untuk variabel aksesibilitas dan lingkungan didetailkan lagi ke dalam beberapa indikator karena variabel yang didapat masih tergolong umum. Hal tersebut dimaksudkan untuk mendapatkan gambaran yang lebih luas dan pengayaan informasi mengenai alasan pemilihan lokasi kafe.

Dalam penelitian ini variabel penelitian yang digunakan, dikelompokkan menjadi dua. Pertama variabel yang memiliki unsur spasial dan kedua variabel yang tidak memiliki unsur spasial. Variabel yang memiliki unsur spasial dalam penelitian ini adalah aksesibilitas, lingkungan, peraturan pemerintah, kompetitor, parkir, dan biaya. Variabel yang tidak memiliki unsur spasial, yaitu visibilitas, ukuran lokasi, dan tenaga kerja.Berikut adalah variabel yang digunakan dalam penelitian ini:

Tabel 2. Variabel Penelitian

\begin{tabular}{|l|l|l|}
\hline \multicolumn{1}{|c|}{ Variabel } & \multicolumn{1}{|c|}{ Definisi Operasional } & \multicolumn{1}{c|}{ Indikator } \\
\hline Aksesibilitas & $\begin{array}{l}\text { Kemudahan lokasi untuk dijangkau dan dilalui } \\
\text { oleh konsumen }\end{array}$ & $\begin{array}{l}\text { - Letak lokasi berdasar fungsi jaringan jalan } \\
\text { - Arus lalu lintas } \\
\text { - Jaringan transportasi umum }\end{array}$ \\
\hline
\end{tabular}




\begin{tabular}{|c|c|c|}
\hline Variabel & Definisi Operasional & Indikator \\
\hline Lingkungan & $\begin{array}{l}\text { Kondisi sekitar lokasi yang mendukung } \\
\text { keberadaan aktivitas }\end{array}$ & $\begin{array}{l}\text { - Keberadaan aktivitas pendukung } \\
\text { - Ketersediaan jaringan prasarana lingkungan } \\
\text { - Karakteristik penduduk } \\
\text { - Tingkat kriminalitas lingkungan }\end{array}$ \\
\hline Peraturan Pemerintah & $\begin{array}{l}\text { Aturan mengenai larangan aktivitas-aktivitas } \\
\text { tertentu di suatu lokasi }\end{array}$ & - Kesesuaian dengan arahan rencana pola ruang \\
\hline Kompetitor & $\begin{array}{l}\text { Keberadaan aktivitas yang memiliki segmentasi } \\
\text { pelayanan dan produk yang sama }\end{array}$ & $\begin{array}{l}\text { - Jumlah dan jarak lokasi sejenis dalam satu } \\
\text { lingkungan }\end{array}$ \\
\hline Parkir & $\begin{array}{l}\text { Ruang untuk transportasi pribadi yang digunakan } \\
\text { oleh konsumen }\end{array}$ & - Ketersediaan parkir \\
\hline Visibilitas & Kemudahan lokasi untuk dilihat dari jarak tertentu & - Kenampakan lokasi dari jalan utama \\
\hline Ukuran Lokasi & Kemampuan lokasi untuk menampung aktivitas & - Luas lahan untuk aktivitas bisnis \\
\hline Tenaga Kerja & $\begin{array}{l}\text { Keberadaan sumber daya manusia untuk } \\
\text { kegiatan operasional }\end{array}$ & - Ketersediaan tenaga kerja \\
\hline Biaya & $\begin{array}{l}\text { Biaya awal yang harus di keluarkan untuk } \\
\text { memperoleh lokasi }\end{array}$ & - Biaya mendapatkan lokasi \\
\hline
\end{tabular}

Sumber: Khoirul, Muhammad, dkk., 2017

\subsection{Populasi dan Sampel}

Sarwono (2006:111) mendefinisikan populasi sebagai keseluruhan unit analisis yang sedang diteliti. Dalam penelitian ini populasi yang dimaksud adalah kafe-kafe yang ada di Kota Surakarta.Untuk mengetahui populasi kafe yang aktual di Kota Surakarta maka dilakukan penggabungan data dari beberapa sumber, antara lain: DPPKAD, DPMPTSP, DINPAR, dan juga menggunakan akun media sosial (instagram), yaitu @kulinerdisolo. Proses penggabungan data dilakukan karena tidak ada sumber baku untuk unit analisis yang dapat digunakan sebagai dasar dalam melakukan penelitian ini.Jadi terlebih dahulu dikumpulkan data-data mengenai lokasi kafe dan restoran dari dinas yang berkaitan menangani data tersebut serta dilakukan penambahan menggunakan daftar kafe dan restoran dari akun @kulinerdisolo untuk menambah referensi mengenai lokasi yang sesuai dengan objek penelitian yang dimaksud. Dari hasil penggabungan dan pemilahan berdasarkan karakter kafe yang dipahami oleh penulis akhirnya didapatkan populasi kafe di Kota Surakarta berjumlah 89 kafe.

Sedangkan sampel adalah sub dari keseluruhan unit analisis yang dipilih untuk kemudian dipelajari lebih lanjut (Sarwono, 2006:111). Dalam penelitian ini sampel yang digunakan adalah kafe yang berusia minimal satu tahun sebelum penelitian ini dilakukan atau kafe tersebut maksimal sudah ada sejak pertengahan tahun 2016. Pembatasan waktu berdiri kafe minimal satu tahun didasarkan pada penelitian Parsa, dkk (2005:305) bahwa pada saat bisnis kuliner yang telah berjalan selama satu tahun maka lebih dari $30 \%$ dari yang ada akan berhenti beroperasi karena berbagai masalah teknis yang dialami. Kafe yang sudah berdiri lebih dari satu tahun dalam kasus ini dianggap telah melalui periode-periode krisis yang biasa dialami oleh usaha-usaha yang berkaitan dengan kuliner.

Dikarenakan tidak ada informasi mengenai waktu pendirian kafe yang valid baik dari instansi atau dari sumber yang lain maka dalam penelitian ini memanfaatkan fasilitas review yang disediakan oleh google maps. Dalam fasilitas review yang disediakan oleh google maps terdapat catatan mengenai waktu ketika masyarakat melakukan review terhadap kafe tersebut. Catatan waktu yang diambil dalam penelitian ini adalah one year ago yang artinya kafe tersebut telah berdiri minimal satu tahun sebelum penelitian ini dilakukan. Dari 89 kafe yang didapatkan dan disesuaikan dengan review yang terdapat pada profil kafe yang ada di google maps diperoleh 63 kafe yang menjadi sampel dalam penelitian. Dari 63 kafe yang menjadi sampel hanya ada 59 kafe yang bersedia untuk menjawab mengenai faktor yang dipertimbangkan dalam pemilihan lokasi, sedangkan kafe yang lain tidak bersedia karena berbagai alasan teknis yang tidak bisa disebutkan.

\subsection{Teknik Analisis}

Dalam penelitian ini teknik analisis utama yang digunakan adalah analisis faktor. Akan tetapi, khusus untuk variabel penelitian yang memiliki unsur spasial selain digunakan analisis faktor, juga akan dipadankan dengan data-data spasial tematik yang menyesuaikan dengan variabel terkait dalam bentuk peta. Hal tersebut dilakukan untuk mengonfirmasi hasil dari analisis faktor serta digunakan untuk memahami mengenai alasan pemilihan lokasi dari para pemilik kafe di Kota Surakarta. 
Analisis faktor yang merupakan analisis utama dalam penelitian ini adalah teknik matematik dan statis yang dirancang untuk meneliti variabel dalam set tertentu (Hardjodipuro, 1988:3). Tujuan dari analisis ini adalah mencoba menjelaskan suatu set variabel ke dalam faktor yang lebih kecil dari jumlah variabel yang didapatkan atau analisis faktor juga bisa disebut sebagai alat untuk meringkas dari sejumlah variabel penelitian menjadi beberapa faktor yang saling berhubungan satu sama lain. Kelompok faktor tersebut ditentukan berdasarkan pengaruh dari setiap variabel dalam proses pemilihan lokasi kafe.

Dalam penelitian ini input data yang digunakan dalam melakukan analisis faktor adalah kuesioner mengenai penilaian faktor pemilihan lokasi yang didapatkan dari pemilik atau pengelola kafe. Penilaian faktor yang ada dalam kuesioner menggunakan skala pengukuran sikap Likert. Skala Likert digunakan untuk mengukur sikap responden dalam suatu penelitian. Sikap dalam skala Likert dimulai dari yang paling negatif hingga paling positif, sebagai contoh: sangat tidak setuju untuk nilai paling negatif hingga sangat setuju untuk nilai yang paling positif (Sarwono, 2006:96).

Untuk melakukan pengolahan data maka skala Likert kemudian diberi angka-angka sebagai simbol agar dapat dilakukan perhitungan. Umumnya pernyataan sangat tidak setuju diberi angka 1 dan terus bertambah hingga pernyataan sangat setuju diberi angka tertinggi. Nilai dari angka-angka tersebut relatif karena angka-angka tersebut hanya merupakan simbol dan bukan angka sebenarnya. Penelitian ini menggunakan skala Likert dengan interval 7 poin karena menurut Finstad (2010:109) skala Likert dengan 7 poin memiliki hasil yang lebih akurat karena jumlah jawaban yang berlainan lebih sedikit daripada interval yang lain, mudah digunakan, dan lebih baik dalam merepresentasikan hasil evaluasi dari para responden.

\section{HASIL DAN PEMBAHASAN}

\subsection{Karakteristik Pemilihan Lokasi Kafe di Kota Surakarta}

Salah satu penunjang perekonomian Kota Surakarta adalah sektor perdagangan dan jasa. Sub sektor perdagangan dan jasa yang sedang tumbuh di Kota Surakarta salah satunya adalah penyediaan jasa makanan dan minuman atau yang biasa disebut restoran atau rumah makan. Salah satu konsep restoran yang mulai mengisi ruang di Kota Surakarta adalah restoran yang berbentuk kafe. Dalam beberapa waktu terakhir pertumbuhan kafe semakin pesat di Kota Surakarta terutama di akhir tahun 2015 dan awal tahun 2016.

Perkembangan kafe di Kota Surakarta dalam beberapa waktu terakhir mengalami peningkatan yang cukup pesat. Jenis-jenis kafe seperti casual, coffee shop, dan tradisional yang berpijak terhadap konsep budaya yang telah ada mulai mengisi ruang-ruang perkotaan yang tersedia dan membaur menjadi salah satu aktivitas malam yang ada di Kota Surakarta. Ruang yang disediakan kafe telah menjadi salah satu alternatif ruang untuk menyalurkan kegiatan interaksi sosial masyarakat Kota Surakarta, selain kegiatan-kegiatan lain yang bisa ditunjang dan diakomodasi dengan keberadaan kafe.

Secara keruangan sampel dari populasi kafe di Kota Surakarta cenderung berlokasi di Kota Surakarta. Kafe-kafe tersebut banyak mengelompok di dua kecamatan, yaitu Kecamatan Banjarsari dengan 20 kafe (34\%) dan Kecamatan Laweyan dengan 23 kafe (39\%). Sedangkan di Kecamatan Pasar Kliwon yang berada di selatan Kota Surakarta hanya terdapat 2 kafe atau hanya 3\% dari total sampel kafe yang ada di Kota Surakarta. Berikut merupakan elaborasi dari setiap variabel yang digunakan dalam penelitian mengenai faktor-faktor yang dipertimbangkan dalam proses pemilihan lokasi kafe di Kota Surakarta.

\section{Aksesibilitas}

Aksesibilitas memiliki keterkaitan yang erat dengan kondisi jaringan jalan yang ada, kondisi di Kota Surakarta yang sebagian besar jaringan jalannya tergolong baik dan hanya sebagian kecilnya yang mengalami kerusakan menjadi penunjang bagi seluruh masyarakat ketika akan melakukan aktivitas terutama memberikan pilihan lokasi yang lebih beragam pada para pemilik kafe.Sebagian besar lokasi kafe memilih untuk berlokasi di jaringan jalan lokal, hal tersebut dikarenakan jalan lokal merupakan jaringan jalan yang digunakan untuk mengakomodasi kegiatan-kegiatan yang terjadi antara pusat-pusat kegiatan lokal di Kota Surakarta. 


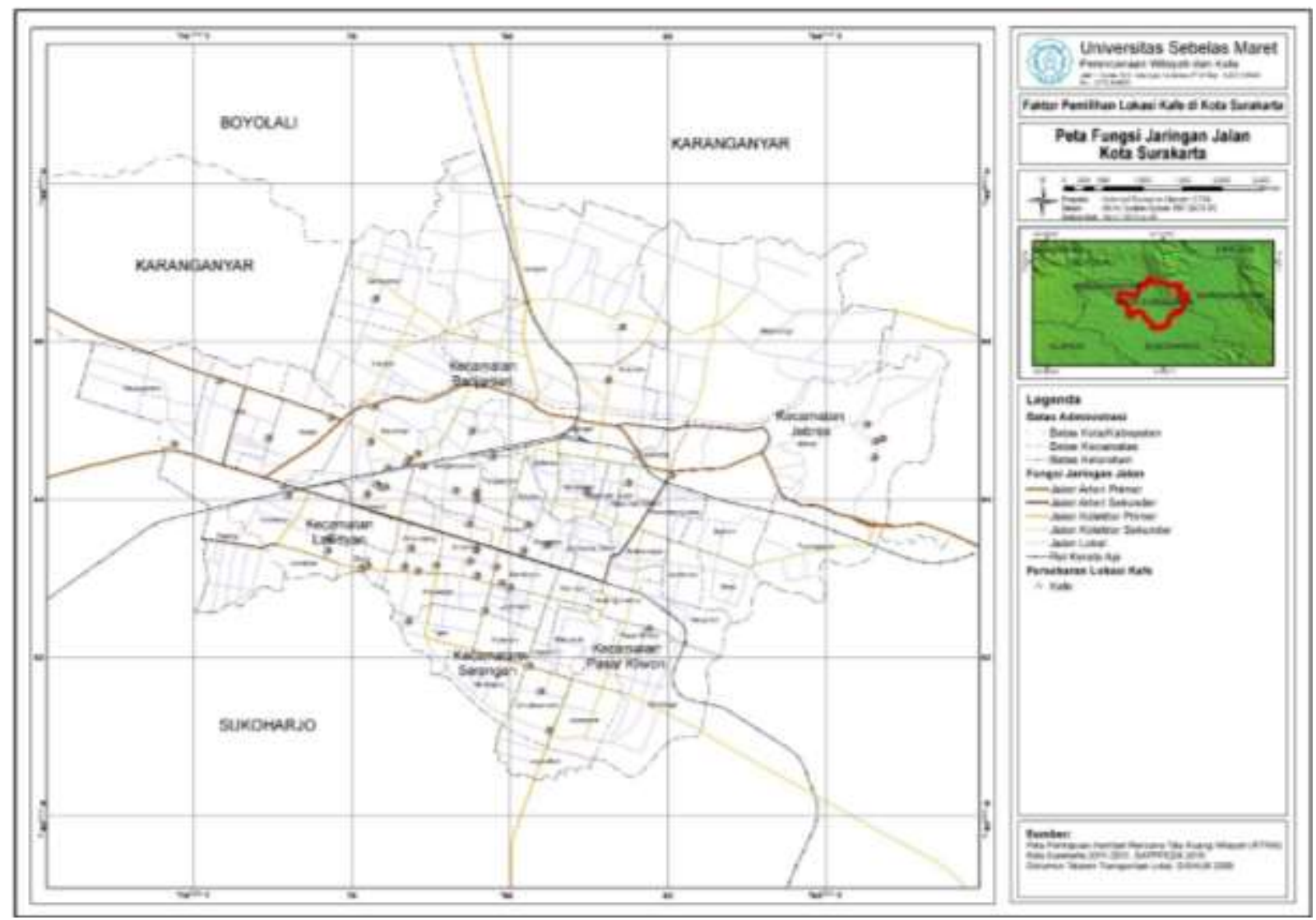

Gambar 1. Peta Fungsi Jaringan Jalan Kota Surakarta

Tingkat keramaian dari jaringan jalan yang dipilih merupakan jalan-jalan dengan kondisi lalu lintas yang cenderung padat. Lalu lintas yang ramai ini sejalan dengan memperbesar kemungkinan untuk mendapatkan konsumen yang lebih banyak karena akan semakin banyak orang yang mengetahui tentang lokasi kafe. Meskipun begitu terdapat kafe yang cenderung memilih untuk berada di jaringan jalan yang relatif tidak padat. Pilihan tersebut diambil karena para pemilik ingin lebih menawarkan suasana yang cenderung nyaman dan tenang dari ramainya kendaraan yang berlalu-lalang sehingga meminimalkan dampak gangguan yang bisa mengganggu atau merusak suasana dariinteraksi yang sedang berlangsung di kafe tersebut.

Kehadiran transportasi umum belum banyak menjadi perhatian atau masuk dalam perhitungan dari para pemilik kafe ketika akan menentukan lokasi. Hal tersebut didasarkan bahwa masyarakat Kota Surakarta secara umum masih mengandalkan transportasi pribadi ketika akan bepergian dari satu lokasi menuju ke lokasi yang lain. Ketidaktersediaan sarana transportasi umum sangatlah minim sekali dampaknya terhadap kemudahan untuk mencapai lokasi kafe. Di sisi lain transportasi umum yang belum sepenuhnya terintegrasi sertajam operasional transportasi umum yang terbatas membuat kehadiran transportasi umum belum begitu banyak dipertimbangkan oleh para pemilik kafe di Kota Surakarta.

\section{Lingkungan}

Lingkungan dengan suasana atau keadaan yang kondusif dan dapat memberikan dukungan positif secara tidak langsung akan memudahkan dalam berjalannya kegiatan kafe serta memungkinkan terjadinya pengembangan usaha kafe yang lebih cepat. Kondisi lingkungan yang berhubungan dalam pemilihan lokasi kafe tersebut antara lain tentang keberadaan dari aktivitas-aktivitas pendukung untuk kegiatan kafe, ketersediaan prasarana lingkungan yang memadai, karakter penduduk yang ada di sekitar lokasi, serta tingkat keamanan dari lokasi kafe.

Aktivitas pendukung yang banyak dipertimbangkan oleh para pemilik kafe di Kota Surakarta adalah aktivitas yang berkaitan dengan pendidikan yang tersebar di sekitar lokasi kafe. Meskipun kafe yang ada memiliki segmentasi atau target konsumen dari segala umur akan tetapi lokasi-lokasi tersebut memang menjadi daya tarik tersendiri bagi para remaja atau anak muda yang merupakan kelompok yang paling banyak menyalurkan kegiatan-kegiatan di luar rumahnya di lokasilokasi seperti ini. 


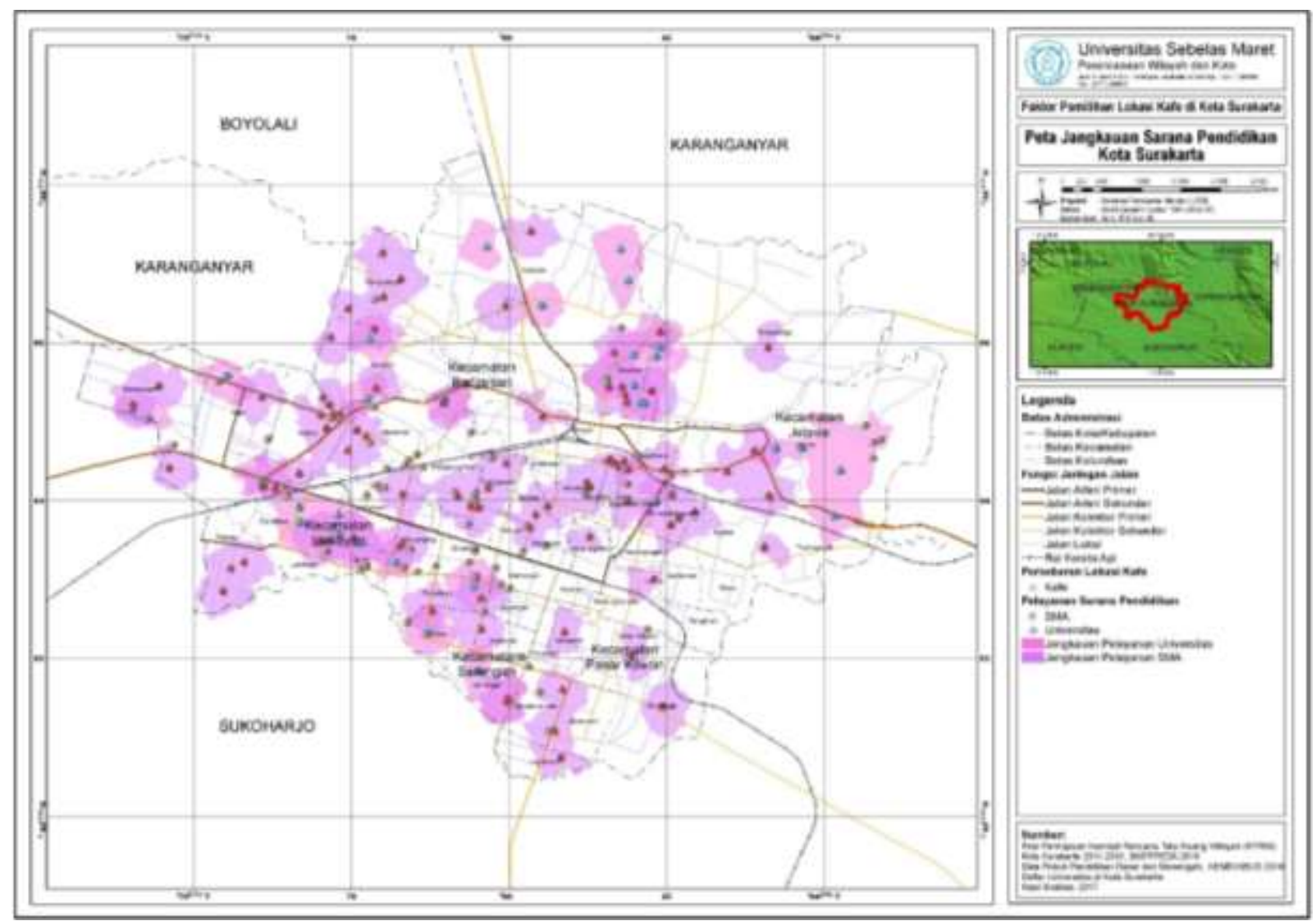

Gambar 2. Peta Jangkauan Sarana Pendidikan Kota Surakarta

Untuk prasarana lingkungan yang berhubungan dalam pemilihan lokasi seperti, jaringan listrik, jaringan air bersih, dan jaringan persampahan secara umum di Kota Surakarta sudah terlayani dengan baik. Kondisi prasarana lingkungan Kota Surakarta yang sudah tersedia dengan baik membuat keberadaannya bukan menjadi faktor yang paling penting meskipun dalam proses pemilihan lokasi hal tersebut tetap dimasukkan menjadi salah satu aspek yang perlu untuk dipertimbangkan dan dipenuhi oleh lokasi terpilih.

Pemilik kafe di Kota Surakarta cenderung memilih daerah-daerah yang didominasi oleh keluarga dengan tingkat ekonomi menengah ke atas. Tingkat ekonomi yang seperti itu diharapkan dapat menerima dan menjangkau produk yang ditawarkan oleh kafe. Terkait dengan komposisi umurnya, para pemilik lebih cenderung memilih daerah yang komposisi kaum mudanya lebih mendominasi. Komposisi kelompok muda yang cenderung mendominasi menandakan bahwa di daerah tersebut memiliki potensi konsumen yang tinggi karena umumnya para pengunjung kafe didominasi oleh kalangan muda.

Untuk tingkat keamanan, kafe di Kota Surakarta banyak berlokasi di daerah yang memiliki tingkat kriminalitas (pencurian) paling tinggi di Kota Surakarta yakni di Kecamatan Banjarsari dan Kecamatan Laweyan. Meskipun begitu, angka kriminalitas yang ada di kedua wilayah tersebut masih bisa ditoleransi dan masih jauh dari predikat daerah yang rawan tindak kriminal. Di sisi lain dua daerah yang sering mengalami tindak pencurian tadi memiliki kemungkinan didominasi oleh masyarakat yang tergolong mampu dan aktivitas ekonomi yang lebih tinggi dari wilayah yang lain sehingga tindak kriminal sering terjadi di daerah tersebut. Hal tersebut tentu akan menjadi peluang tersendiri bagi para pemilik kafe karena daerah yang dipilih mempunyai segmentasi yang sesuai dengan usaha kafe yang akan dikembangkan.

\section{Peraturan Pemerintah}

Selain meminimalkan potensi permasalahan dengan pihak pemerintah di kemudian hari, kesesuaian dengan aturan juga bisa memberikan insentif-insentif tertentu bagi para pemilik usaha karena sudah bisa mengikuti peraturan yang ditetapkan oleh pemerintah daerah. Sebagian besar pemilik kafe di Kota Surakarta memilih lokasi yang berada di wilayah 
yang ditetapkan untuk pengembangan kegiatan komersial. Di sisi lain, ada pula pemilik kafe yang memilih lokasi di area yang diperuntukkan bagi aktivitas permukiman.

Penentuan lokasi kafe di daerah yang memiliki arahan untuk komersial atau permukiman tidak lain karena kedua guna lahan tersebut memiliki potensi konsumen yang besar baik dari daya tarik aktivitas komersial yang menarik masyarakat dalam jumlah yang besar ataupun potensi penduduk yang tinggal di lingkungan permukiman sekitar lokasi kafe. Meskipun terletak di area yang arahannya untuk peruntukan permukiman, akan tetapi kegiatan kafe umumnya dapat berjalan dengan lancar. Hal tersebut terjadi karena sebelumnya para pemilik kafe melakukan pendekatan kepada masyarakat di sekitar lokasi sehingga bisa diterima dengan baik di lingkungan tersebut.

\section{Kompetitor}

Kemampuan untuk membaca keberadaan, kekuatan, serta peluang dari hadirnya kompetitor di sekitar lokasi yang akan dipilih sebagai lokasi kafe bisa memberikan jaminan mengenai keberlangsungan dari usaha yang nantinya dijalankan karena dapat bersaing dengan usaha sejenis yang dijalankan. Secara umum para pemilik kafe di Kota Surakarta memilih untuk berlokasi di daerah yang dekat dengan lokasi-lokasi yang memiliki usaha sejenis.

Kedekatan yang ada memberikan satu peluang bagi para pemilik kafe dalam kegiatan promosi karena secara tidak langsung konsumen yang akan menuju ke lokasi dari kompetitor kemungkinan besar secara tidak sengaja akan melihat keberadaan dari lokasi kafe yang dimiliki. Dari mengetahui keberadaan kafe lain di sekitar kafe yang biasa dikunjungi dapat muncul rasa penasaran dari diri konsumen dengan mencoba mengunjungi kafe tersebut untuk sesekali mendapatkan suasana yang berbeda dari yang biasanya didapatkan.

\section{Parkir}

Keberadaan ruang parkir yang nyaman dan aman sehingga bisa memenuhi ekspektasi dan keinginan dari para pengunjung akan menjadi penilaian tersendiri bagi para konsumen untuk datang kembali ke lokasi tersebut. Para pemilik kafe di Kota Surakarta berusaha menyediakan ruang parkir bagi para konsumennya menggunakan ruang-ruang yang masih tersedia dari lokasi kafe yang dikembangkan.

Ketika ruang tersebut tidak cukup untuk memfasilitasi kendaraan pribadi konsumen atau pemilik tidak memiliki ruang yang memadai dari lokasi usahanya, pemilik kafe akan mencari alternatif lain yang bisa digunakan untuk parkir baik menggunakan lahan atau ruang kosong di sekitar lokasi atau menggunakan tepi jalan umum di depan lokasi. Umumnya tepi jalan umum menjadi solusi bagi para pemilik kafe untuk kebutuhan terhadap ruang parkir karena tidak terlalu memberikan beban terhadap pengeluaran yang harus dilakukan oleh para pemilik. Penggunaan tepi jalan umum sebagai alternatif parkir juga tidak memerlukan perizinan yang lama, biasanya para pemilik akan mendiskusikannya dengan masyarakat sekitar untuk meminta izin terkait akan pemanfaatan tepi jalan yang ada sebagai ruang parkir.

\section{Visibilitas}

Ketika lokasi mudah untuk dilihat atau diamati maka akan membuat lokasi lebih mudah diingat oleh para pengunjung atau masyarakat yang tengah lewat di sekitar lokasi. Kemudahan untuk diingat tersebut menjadi suatu keuntungan karena akan memperbesar kemungkinan untuk masyarakat kembali lagi ke tempat tersebut. Hal tersebut oleh para pemilik kafe diwujudkan dengan memberikan identitas yang kuat menggunakan bentuk bangunan atau dengan memanfaatkan desain eksterior dari lokasi sehingga bisa menjadi suatu ciri yang kuat bagi para pengunjung atau masyarakat umum.

Selain itu, umumnya para pemilik akan menggunakan aksen-aksen khusus seperti papan berisikan nama dari kafe dengan ukuran yang cukup besar dan biasanya diletakkan di depan lokasi sehingga bisa menjadi penanda untuk masyarakat yang sedang mencari kafe tersebut. Terkadang pemilik kafe juga memasang beberapa petunjuk arah di jalanjalan yang dianggap strategis dan biasa menjadi akses utama masyarakat sehingga memudahkan masyarakat untuk menuju ke lokasi tersebut.

\section{Ukuran Lokasi}

Kemampuan lokasi dalam mengakomodasi ruang yang dibutuhkan untuk penerapan konsep kafe akan memberikan kelancaran selama berjalannya kegiatan kafe dan bisa memberikan kenyamanan yang lebih bagi para konsumen karena 
ada banyak alternatif dari bagian-bagian kafe yang bisa digunakan oleh pengunjung. Untuk permasalahan mengenai kebutuhan ruang, para pemilik kafe akan menyesuaikan dengan konsep atau karakter yang ingin diterapkan.

Umumnya pemilik kafe menyediakan dua tata letak ruangan yang bisa digunakan oleh para pengunjung. Ruang di dalam bangunan yang relatif lebih nyaman dan tenang untuk digunakan dalam beraktivitas ataupun ruang di luar bangunan untuk mencari suasana yang lebih natural sehingga menghadirkan kondisi yang lebih santai untuk berkomunikasi satu dengan lainnya.

\section{Tenaga Kerja}

Dalam prosesnya kafe memang membutuhkan beberapa orang yang bisa bekerja sama untuk dapat menjalankan kegiatan operasional sehari-hari. Akan tetapi kebutuhan tersebut tidak harus dipenuhi oleh masyarakat dari lingkungan sekitar lokasi. Operasional kafe yang jarang membutuhkan kemampuan khusus, kecuali di beberapa posisi membuat peluang tersebut bisa diisi oleh masyarakat umum yang tidak terbatas hanya dari lingkungan tersebut.

Orang-orang yang membantu dalam hal operasional kafe juga sangat jarang sekali berasal dari lingkungan sekitar kafe meskipun umumnya masih berasal dari masyarakat di dalam Kota Surakarta. Namun ada juga beberapa kafe yang memberikan sejumlah kuota dari keseluruhan orang yang dibutuhkan untuk masyarakat di sekitar lokasi kafe. Hal tersebut dimaksudkan agar usaha kafe bisa diterima dengan baik oleh masyarakat dan turut membantu dalam kegiatan ekonomi masyarakat sekitar.

\section{Biaya}

Lokasi yang menyebabkan biaya operasional menjadi tinggi akan mempengaruhi keseimbangan kondisi keuangan dari kafe ketika pemasukan yang didapat tidak bisa mengimbanginya dan kondisi tersebut akan menjadi penghambat dalam proses pengembangan kafe yang akhirnya bisa membuat kafe berhenti beroperasi. Para pemilik kafe di Kota Surakarta secara umum akan mencari lokasi yang tidak terlalu banyak membebani elemen pengeluaran namun mempunyai peluang yang menguntungkan ketika dikembangkan usaha kafe.

Sebagian besar pemilik kafe lebih memilih untuk mencari lokasi dengan jangkauan harga yang tidak terlalu tinggi. Lokasi yang dipilih biasanya tidak berada dekat dengan jalan-jalan utama di Kota Surakarta, akan tetapi lokasi tersebut memiliki jarak yang tidak terlalu jauh dengan jalan utama dan masih termasuk dalam jangkauan dari jalan utama sehingga para pengunjung masih bisa dengan mudah untuk mencapainya. Di sisi lain, kondisi jaringan jalan di Kota Surakarta yang tergolong baik karena sangat sedikit sekali persentase jalan yang mengalami kerusakan membuat lokasi-lokasi dengan harga tengah menjadi alternatif pilihan bagi para pemilik yang tidak perlu sulit untuk memikirkan pengeluaran yang harus ditanggung.

\subsection{Faktor Pemilihan Lokasi Kafe di Kota Surakarta}

Dari tahapan analisis faktor yang sudah dilakukan mulai dari tahap uji validitas dan reliabilitas hingga tahap rotasi faktor dapat disimpulkan bahwa analisis faktor dapat digunakan dalam penelitian ini dan diperoleh 4 faktor yang secara garis besar menjadi representasi mengenai pemilihan lokasi kafe di Kota Surakarta. Kelompok faktor yang mempengaruhi pemilihan lokasi kafe di Kota Surakarta, antara lain: fleksibilitas lokasi, kesesuaian lokasi, dukungan sekitar lokasi, dan faktor tambahan.

Tabel 3. Component Transformation Matrix

\begin{tabular}{|c|c|c|c|c|}
\hline Component & $\mathbf{1}$ & $\mathbf{2}$ & $\mathbf{3}$ & $\mathbf{4}$ \\
\hline $\mathbf{1}$ &, 635 &, 473 &, 491 &, 363 \\
\hline $\mathbf{2}$ &,- 644 &, 760 &, 077 &, 034 \\
\hline $\mathbf{3}$ &,- 422 &,- 445 &, 689 &, 387 \\
\hline $\mathbf{4}$ &,- 054 &,- 030 &,- 528 &, 847 \\
\hline
\end{tabular}

Sumber: Khoirul, Muhammad, dkk., 2017

Faktor pertama adalah faktor fleksibilitas lokasi. Faktor pertama terdiri dari faktor jalan utama, arus lalu lintas, kemudahan lokasi dilihat, aktivitas pendukung, dan keberadaan pesaing. Faktor pertama yang merepresentasikan mengenai kemudahan lokasi untuk ditemukan dan masyarakat bisa dengan nyaman mencapainya merupakan pertimbangan utama bagi para pemilik kafe di Kota Surakarta dalam menentukan lokasi. 
Permasalahan mendasar mengenai pertimbangan lokasi kafe di Kota Surakarta adalah mendekatkan keberadaan lokasi kafe dengan calon-calon konsumen potensial. Hal tersebut diwujudkan oleh pemilik kafe di Kota Surakarta dalam bentuk pemilihan lokasi yang berada dalam jangkauan dari jalan-jalan utama yang memiliki arus cukup ramai sehingga lokasi kafe bisa diamati dan ditemukan dengan mudah oleh masyarakat yang sedang beraktivitas atau berlalu-lalang di sekitar lokasi kafe.

Lokasi kafe juga berada di sekitar lokasi dari aktivitas-aktivitas yang bisa mendatangkan pengunjung potensial, seperti pendidikan dan perdagangan. Lokasi kafe yang cenderung mengelompok sehingga menghasilkan aglomerasi kelompok kafe merupakan satu bentuk pendekatan untuk bisa menarik lebih banyak konsumen karena menghadirkan pilihan kafe yang beragam dalam lokasi yang relatif berdekatan antara satu lokasi dengan lokasi lain.

Faktor kedua adalah kesesuaian lokasi. Faktor kedua terdiri dari ketersediaan ruang parkir, luas lokasi, peraturan, dan biaya lokasi. Faktor kedua lebih merepresentasikan mengenai kemampuan dari lokasi terpilih untuk dapat mengakomodasi kebutuhan dari kegiatan kafe yang akan dijalankan dengan tetap memperhatikan kemampuan keuangan dari pemilik. Kesesuaian lokasi terutama ditentukan dari ketersediaan ruang yang digunakan untuk mengaplikasikan konsep kafe yang diinginkan oleh pemilik.

Ketersediaan ruang juga termasuk untuk menampung kendaraan pribadi dari para pengujung kafe dalam bentuk ruang parkir. Harga dari lokasi juga sangat menentukan karena berhubungan dengan kemampuan keuangan yang dimiliki oleh pemilik kafe untuk menjalankan usahanya. Serta kesesuaian dengan aturan yang bisa menjamin keberlangsungan usaha dan peluang mengenai kemungkinan konsumen dari arahan guna lahan yang menjadi elemen aturan tata ruang.

Lokasi yang memiliki fleksibilitas baik akan tetapi tidak mempunyai ruang yang cukup untuk menerapkan konsep yang menjadi daya tarik bagi para pengunjung akan menjadi sia-sia karena pasti akan mengalami permasalahan di masa yang akan datang. Kesesuaian lokasi juga menjadi salah satu penentu keberlangsungan dari usaha karena sangat jarang ditemui lokasi di Kota Surakarta yang memiliki fleksibilitas baik serta ruang yang cukup luas ditawarkan dengan biaya yang murah, hal semacam itu hanya bisa ditemukan di wilayah pinggir kota yang kurang menarik bagi para konsumen. Sehingga para pemilik kafe di Kota Surakarta menyiasatinya dengan memilih lokasi yang masih berada dalam jangkauan wilayah dengan fleksibilitas baik karena dalam wilayah tersebut masih bisa ditemui lokasi yang memberikan ruang yang cukup dengan harga yang sesuai kemampuan pemilik.

Faktor ketiga adalah dukungan sekitar lokasi. Faktor ketiga terdiri dari ketersediaan prasarana lingkungan, karakter penduduk, serta tingkat keamanan dari lingkungan di sekitar lokasi kafe yang terpilih. Faktor ketiga merepresentasikan mengenai elemen-elemen yang ada di sekitar lokasi yang bisa menunjang dan mempermudah dalam kegiatan operasional kafe.

Prasarana lingkungan yang telah disediakan oleh pemerintah Kota Surakarta antara satu wilayah dengan wilayah lain relatif sudah memadai sehingga tidak terlalu signifikan memberikan pengaruh terhadap proses pemilihan lokasi. Begitu pula dengan tingkat kriminalitas di Kota Surakarta yang tergolong rendah sehingga secara umum keamanan di Kota Surakarta tergolong baik. Sedangkan untuk karakter penduduk mungkin memberikan sedikit pertimbangan dalam memilih lokasi yang sesuai meskipun tidak signifikan karena terdapat perbedaan baik dari segi jumlah penduduk atau dari karakter ekonomi masyarakat di Kota Surakarta.

Faktor keempat adalah faktor tambahan. Kelompok faktor yang terdiri dari keberadaan transportasi umum dan ketersediaan tenaga kerja ini cenderung tidak memberikan pengaruh dalam pemilihan lokasi kafe di Kota Surakarta. Hal tersebut terjadi karena masyarakat Kota Surakarta masih menggunakan transportasi pribadi sebagai moda transportasi andalan ketika bepergian serta kebutuhan tenaga kerja yang tidak membutuhkan keahlian khusus sehingga tidak tergantung pada masyarakat di sekitar lingkungan lokasi kafe. Faktor ini bisa disebut hanya sebagai pelengkap saja dari faktor-faktor yang lain karena tanpa pertimbangan akan faktor ini kegiatan usaha kafe di Kota Surakarta masih bisa tetap berjalan dengan stabil.

\section{KESIMPULAN}

Tahap pemilihan lokasi merupakan salah satu tahap terpenting dalam memulai suatu usaha karena akan mempengaruhi keberlangsungan usaha yang direncanakan. Secara umum pemilihan lokasi kafe di Kota Surakarta ditentukan oleh empat kelompok faktor mulai dari fleksibilitas lokasi, kesesuaian lokasi, dukungan sekitar lokasi, hingga 
faktor tambahan. Pemilik kafe di Kota Surakarta menempatkan kemudahan lokasi untuk dicapai oleh para pengunjung menjadi faktor utama karena keberadaan pengunjung yang secara konsisten datang ke kafe merupakan sumber utama pemasukan sehingga kafe tetap bisa berjalan. Selanjutnya pemilik mempertimbangkan mengenai lokasi yang sesuai dengan kemampuan yang dimiliki dengan tetap memperhatikan ketersediaan ruang yang memadai sehingga bisa membuat pengunjung merasa nyaman ketika ada di kafe. Dukungan sekitar lokasi memberikan kontribusi positif terhadap kelancaran dari kegiatan usaha kafe sehingga operasional kafe bisa memberikan pelayanan yang maksimal terhadap pengunjung. Sedangkan untuk faktor tambahan belum menjadi bagian penting karena karakter masyarakat Kota Surakarta yang masih memanfaatkan transportasi umum sebagai moda transportasi utama serta kebutuhan tenaga kerja untuk operasional kafe yang jarang membutuhkan keterampilan khusus.

\section{DAFTAR PUSTAKA}

Ariani, Wahyu Dorothea. (2009). Manajemen Operasi Jasa. Yogyakarta: Graha Ilmu

Bernhardt, Andrew and Linda Stoll. (2010). Creating Third Places: Places Where Communities Gather. Downtown Economics, University of Wisconsin-Extension, Issue 172. Diakses dari: http://fyi.uwex.edu

Chen, Li-Fei dan Chih-Tsung Tsai. (2015). Data Mining Framework Based on Rough Set Theory to Improve Location Selection Decisions: A Case Study of A Restaurant Chain. Tourism Management, 53, 197-206.http://www.sciencedirect.com

Damajani, Rian R.R. (2008). Vernakularisme, Informalitas, dan Urbanisme: Café sebagai Ekspresi Gaya Hidup Kontemporer. Journal Visual Art \& Design, 2(2), 141-158.http://journals.itb.ac.id

Finstad, Kraig. (2010). Response Interpolation and Scale Sensitivity: Evidence Against 5-Point Scales. Journal of Usability Studies,5, 104-110. http://uxpajournal.org

Goodall, Brian. (1972). The Economics of Urban Areas. Oxford: Pergamon Press

Hardjodipuro, Siswoyo. (1988). Aplikasi Komputer dan Analisis Multivariat: Analisis Faktor. Jakarta: Direktorat Jenderal Pendidikan Tinggi.

Hariwan, Peggy dan Inggi Silviatni. (2014). Perancangan Model Bisnis Cafe Zapateria. Jurnal Manajemen Bisnis Indonesia, 2(1), 5367. http://fmi.unairs1manajemen.com

Indarti, Nurul.(2014). Business Location and Success: The Case of Internet Café Business in Indonesia. Gadjah Mada International Journal of Business, 6(2), 171-192. https://jurnal.ugm.ac.id

Maharani, Nurlina. (2016). Konsumsi Ruang Kafe: Panggung Publik yang Personal (Studi Kasus Dinamika Pola Konsumsi dan Pemaknaan Ruang Kafe di Kota Yogyakarta). Yogyakarta: Universitas Gadjah Mada.

Oldenburg, Ray. (1997). Our Vanishing "Third Places". Planning Commissioners Journal, Winter 1996-97(25). http://plannersweb.com

Pamungkas, Putradi. (2017). Ruang Terbuka Hijau Solo Baru 9,7 Persen. Diakses dari: http://solo.tribunnews.com/2017/04/01/ruang-terbuka-hijau-solo-baru-97-persen

Park, Kunsoon dan Mahmood A. Khan. (2005). An Exploratory Study to Identify the Site Selection Factors for U.S. Franchise Restaurants. Journal of Foodservice Business Research, 8(1).http://www.tandfonline.com

Parsa, dkk. (2005). Why Restaurants Fail. Cornell Hotel and Restaurant Administration Quarterly, 46, 304322.http://journals.sagepub.com

Putra, Idris Rusadi. (2016). Menjamurnya bisnis cafe di Tanah Air. Diakses dari: http://www.merdeka.com/uang/menjamurnya-bisniscafe-di-tanah-air.html

Republik Indonesia. (2014). Peraturan Menteri Pariwisata dan Ekonomi Kreatif Nomor 10 Tahun 2014 tentang Standar Usaha Kafe. Jakarta. Diaksesdari:http://www.serfitatama.com

Sarwono, Jonathan. (2006). Metode Penelitian Kuantitatif dan Kualitatif. Yogyakarta: Graha IImu

Septiyaning, Indah. (2016). Bisnis Kuliner di Kota Solo Melonjak. Diakses dari: http://www.solopos.com/2016/03/21/kuliner-solobisnis-kuliner-di-kota-solo-melonjak-703134

Smith, Stephen L. J. (1985). Location Patterns of Urban Restaurants. Annals of Tourlsm Research, 12, 581-602. http://www.sciencedirect.com

Sugiyono. (2009). Metode Penelitian Kuantitatif, Kualitatif, dan R\&D. Bandung: Alfabeta.

Tarigan, Robinson. (2005). Perencanaan Pembangunan Wilayah Edisi Revisi. Jakarta: PT. Bumi Aksara.

Tjiptono, Fandy dan Gregorius Chandra. (2011). Service, Quality, \& Satisfaction Edisi 3. Yogyakarta: Andi. 
Desa-Kota, Vol. 1, No. 2, 2019, 108-120

Tzeng, dkk. (2002). Multicriteria Selection for A Restaurant Location in Taipei. Hospitality Management, 21, 171-187. http://www.sciencedirect.com

Wahyudi, Nur. (2014). Analisis Faktor-Faktor Pemilihan Lokasi Usaha terhadap Kesuksesan Usaha Jasa Mikro di Kecamatan Sungai Kunjang. Jurnal Ekonomia, 3(3), 136-143. http://ejurnal.untag-smd.ac.id

Zuliarni, Sri dan Relon Taufik Hidayat. (2013). Analisis Faktor Pertimbangan Pebisnis Restoran Kelas Kecil Di Lingkungan Kampus Universitas Riau Dalam Pemilihan Lokasi Usaha. Jurnal Aplikasi Bisnis, 3(2), 100-119.http://ejournal.unri.ac.id 